\title{
Enemies Within or Without Enemies: "Enemy Aliens" and Internment in Canada \\ during the Second World War
}

\author{
By: Tricia Nowicki
}

Tricia Nowicki (1985 - 2017) took two classes with me, but she taught me more than I taught her. Being in a mechanized wheelchair, she was a notable presence in the classroom. What really made Tricia stand out, though, was her powerfully articulate presence in seminar. For any who imagined a small woman in a mechanized wheelchair to need polite support and gentle handling, Tricia quickly put such notions to rest. She was fearless and suffered no fools. She spoke directly to issues, highlighting debates, pulling at evidence, ably comparing perspectives, and tackling debate with gusto. Her strength and intelligence stood out far more than any wheelchair.

The following essay was from her second-year course with Professor Maureen Lux. It's not a research essay, but rather an exercise in historiography - that is, the history of what is written about a particular subject. One of the great challenges history students face is making sense of complex debates in history, not simply what happened but different interpretations of what happened and what meaning we take from it. This essay looks at four different historians all addressing the same story: the internment of "enemy aliens" people born in or ethnically identified with the enemy countries of Germany, Italy, or Japan during the Second World War. While the basics of the story are agreed upon, each historian has a different assessment of why and how the Canadian government detained these people, whether and how it was justified, and what meaning we should take of this important moment in our country's history. Tricia's essay takes us through each essay, examines their evidence, assessing not only what is said, but also situating the political and ethical dimensions of the story. She understood the disciplinary issues of being a historian; she understood the ethical importance of this story and the debate around it. She was a fine historian.

- Dr. Daniel Samson

During the Second World War (1939-1945), the nations involved in hostilities were split between the Allied and Axis powers. As part of the Allies and a country built on immigration, Canada suddenly found itself having to manage hundreds of thousands of residents whose nationalities were of Axis states, including but not limited to men and women of German, Italian, and Japanese descent. As a result, the Canadian government implemented the Defence of Canada Regulations (DOCR) to restrict distribution of 
dissident information and monitor or ban the activities of people and groups deemed a threat to the safety of the country, such as fascists, pro-Nazis, communists, or conscientious objectors. ${ }^{1}$ The DOCR forced persons of enemy origin, whether immigrants, naturalized citizens, or even Canadian-born nationals, to register as "enemy aliens" with the state and authorized government security forces to arrest and detail anyone suspected of subversion or aiding the enemy without a trial. ${ }^{2}$ Moreover, many "enemy aliens," particularly Japanese families, were subjected to property confiscation, home evacuation, relocation to labour or internment camps, or even deportation or denaturalization. ${ }^{3}$ Historians have treated the Canadian government's internment of persons of enemy origin during the Second World War differently, since some hold a more traditionalist view, arguing "enemy aliens" were prejudicially interned based on ethnicity, while others apply a revisionist perspective, claiming belief in seditious and radical politics or ideologies led to the justifiable internment of "enemy aliens." By examining several articles about "enemy aliens" in Canada in the Second World War, these differences are not only reflected in the background of the authors, choice of subject, and date of publication, but are also revealed in the analysis and interpretation of primary and secondary sources to draw conclusions on why and how the government interned persons of enemy origins identified as subversive or threats to the country.

Since the topic is the focus of many books and articles, the following analysed articles present only a small sample of the varying arguments and perspectives published

\footnotetext{
${ }^{1}$ Marcel Martel, "World War II and the Internment of Enemy Aliens: Circumscribing Personal Freedoms," in Visions: The Canadian History Modules Project, Post-Confederation, eds. P.E. Byrden et al (Toronto: Nelson, 2017), 237-238.

${ }^{2}$ Ibid, 237.

${ }^{3}$ Ibid, 238. See also Bill Waiser, s.v. "Wartime Internment," The Oxford Companion to Canadian History (New York: Oxford University Press, 2004), accessed 23 March 2017.
} 
on the Second World War interment of "enemy aliens" in Canada. In "'Agents Within the Gates': the Search for Nazi Subversives in Canada during World War II," historian Robert H. Keyserlingk argues the threat of persons of enemy origin "turning against the adopted country" was a political myth, and the Canadian government arbitrarily interned peoples from the German community to show control and assuage public fear of a Nazi insurgency. ${ }^{4}$ As it was not only published amidst campaigns lobbying the Canadian government for Japanese Canadian redress but also included as part of On Guard for Thee: War, Ethnicity, and the Canadian State, 1939-1945, a collection of papers presented at a Queen's University symposium with a traditionalist view on how the government dealt with ethnic minorities during the Second World War, "“"Agents Within the Gates" was an opportunity to call attention to the discrimination German Canadians experienced during the war. Furthermore, as a German-born Canadian himself, there is no doubt Keyserlingk's familial background inspired him to focus on "enemy aliens" of German descent, but his knowledge and seasoned past, including service in the Royal Canadian Navy and careers as a Canadian foreign service officer in Germany and history professor at the University of Ottawa, ${ }^{6}$ adds to the scholarship of his article.

Similarly, Pamela Sugiman, a Canadian woman of Japanese descent, identifies with the subjects of her article, "Passing Time, Moving Memories: Interpreting Wartime Narratives of Japanese Canadian Women," but she acknowledges the influential impact

\footnotetext{
${ }^{4}$ Robert H. Keyserlingk, “'Agents Within the Gates': the Search for Nazi Subversives in Canada during World War II," Canadian Historical Review 66, no. 2 (June 1985): 211-212, 237-238.

${ }^{5}$ Norman Hillmer, Bohdan Kordan, and Lubomyr Luciuk, eds., On Guard for Thee: War, Ethnicity, and the Canadian State, 1939-1945 (Ottawa: Canadian Committee for the History of the Second World War, 1988).

6 “Keyserlingk, Robert H.," Encyclopedia.com, accessed 23 March 2017.
} 
her own memories and emotions had on her research. ${ }^{7}$ Nonetheless, a historian and sociology professor at Ryerson University, her expertise in oral history, memory, racism and racialization, and women's history in Canada comes across in "Passing Time, Moving Memories" and definitely strengthens her argument, both from a traditionalist and revisionist perspective. ${ }^{8}$ Like the German Canadian subjects in "Agents Within the Gates," Sugiman claims the Canadian government violated Japanese Canadians due to their ethnicity and interned them without evidence of subversion during the Second World War, "[resulting] in the destruction of a community and trauma to the individuals within it." In addition, "Passing Time, Moving Memories," originally presented at a conference for the Centre for Feminist Research, is a revisionist work to a certain extent, since it focuses on the experiences of female Japanese Canadians during the Second World War, reflecting the growing recognition of feminist and women's history when published, and argues against scholars' previous depiction of Japanese Canadian women as voiceless, powerless, and without agency. ${ }^{10}$

In contrast, the articles by historians Michelle McBride, "The Curious Case of Female Internees,” and Reg Whitaker and Gregory S. Kealey, “A War on Ethnicity? The RCMP and Internment," are principally revisionist, seeing as they were both featured in Enemies Within: Italian and Other Internees in Canada and Abroad, a book compiled after a 1995 conference debating the fascist associations of Italian Canadians interned during the Second World War and arguing "enemy aliens" with political beliefs diverging

\footnotetext{
${ }^{7}$ Pamela Sugiman, "Passing Time, Moving Memories: Interpreting Wartime Narratives of Japanese Canadian Women," in Visions: the Canadian History Modules Project, Post-Confederation, eds. P.E. Bryden et al (Toronto: Nelson, 2017), 252-253.

8 "Pamela Sugiman," Research \& Innovation Spotlight, Ryerson University: Faculty of Arts, accessed 23 March 2017.

${ }^{9}$ Sugiman, 250-251.

${ }^{10}$ Ibid, 250, 264.
} 
from those of the Canadian government posed a genuine threat to national security. ${ }^{11}$ In "Curious Case of Female Internees," McBride claims literature on female internees is virtually non-existent, even through women were a significant presence in Canadian fascist and pro-Nazi organizations before and during war, and her intention is to gender the history of internment by writing them into it. ${ }^{12}$ Moreover, her interest in the Royal Canadian Mounted Police (RCMP), having written her History Masters thesis on how they dealt with Nazism and fascism in Canada from 1934 to $1941^{13}$ is evident, as she suggests the arbitrary confinement of women was due to the irresponsible InterDepartmental Committee on Internment (IDC) rather than the RCMP, who were vital in investigating and tracking subversive activities. ${ }^{14}$ Likewise, Whitaker and Kealey, history professors at York University and the University of New Brunswick, respectively, and specialists on Canadian security and intelligence history, ${ }^{15}$ show a considerable amount of affinity for the RCMP in their article, "War on Ethnicity?" Formerly collaborating on RCMP Security Bulletins, a multi-volume work of assembled and edited security dispatches from before and during the Second World War, ${ }^{16}$ it is not surprising that their article argues the RCMP proficiently separated politics or ideologies from ethnic backgrounds, stating they "were more remarkable for their relative selectivity than for putting 'ethnicity on trial,' striking not at the ethnic communities in general but at the

\footnotetext{
${ }^{11}$ Franca Iacovetta, Roberto Perin, and Angelo Principe, eds., Enemies Within: Italian and Other Internees in Canada and Abroad (Toronto: University of Toronto Press, 2000), vii-viii.

${ }^{12}$ Michelle McBridge, "The Curious Case of Female Internees," in Enemies Within: Italian and Other Internees in Canada and Abroad, eds. Franca Iacovetta, Roberto Perin, and Angelo Principe (Toronto: University of Toronto Press, 2000), 148-152.

${ }^{13}$ Iacovetta, Perin, and Principe, eds., Enemies Within, 414.

${ }^{14}$ McBride, 148-152.

15 "Inventory of Reg Whitaker Fonds," Fonds 0225, York University Archives and Special Collections, Toronto ON, last modified 20 November 2003; "Greg Kealey," History University of New Brunswick: Faculty of Arts, accessed 23 March 2017.

${ }^{16}$ Ibid; Iacovetta, Perin, and Principe, eds., 414 and 416.
} 
ideologically suspect minority." ${ }^{17}$ Furthermore, Whitaker and Kealey suggest the RCMP's surveillance intelligence prevented any subversive plots in Canada by quickly identifying and detaining "enemy aliens" whose activities in fascist or pro-Nazi organizations posed a threat to both the nation and war effort. ${ }^{18}$ Although, in 1990, Prime Minister Brian Mulroney publicly apologized on behalf of the Canadian government for the wrongful treatment and internment of Italian Canadians during the Second World War, ${ }^{19}$ this sentiment is clearly not shared by McBride, Whitaker, and Kealey in their articles published after his statement, viewing "enemy aliens" of Italian (or German) descent not as victims of their ethnic origin, like the Japanese Canadians, but as people with questionable political loyalties.

Each of the articles analysed in this paper combine primary and secondary sources in different ways to show how the Canadian government and its security forces classified and interned supposedly subversive persons of enemy origin during the Second World War. In "'Agents Within the Gates," Keyserlingk uses immigration statistics and records from the Department of External Affairs to de-mythologize the idea that many German immigrants had strong ties to Nazi Germany, showing most German Canadians were either refugees from Nazism or not exposed to the Hitler regime (1933-1945) because they came to Canada before the Depression closed immigration in $1931 .{ }^{20}$ While his article is well-researched, Keyserlingk relies heavily on documents from the William

\footnotetext{
${ }^{17}$ Reg Whitaker and Gregory S. Kealey, "A War on Ethnicity? The RCMP and Internment," in Visions: the Canadian History Modules Project, Post-Confederation, eds. P.E. Bryden et al (Toronto: Nelson, 2017), 270, 273, 274, 277.

${ }^{18} \mathrm{Ibid}, 274$

${ }^{19}$ Iacovetta, Perin, and Principe, eds., vii.

${ }^{20}$ Keyserlingk, 214-215.
} 
Lyon Mackenzie King Diary and Public Archives of Canada, ${ }^{21}$ only examining the situation through the eyes of public officials and not the German Canadian internees, and he is relatively non-comparative by not relating his findings to those of other historians, either Canadian or from abroad, possibly since his study was one of the first of its kind. Although Whitaker and Kealey similarly view "enemy alien" internment through a bureaucratic or RCMP lens, using letters and reports from the National Archives or Canadian Security Intelligence Services (CSIS), they also juxtapose their conclusions with several other historians, including Keyserlingk and McBride. ${ }^{22}$ While Keyserlingk cites newspaper articles, specifically from the Hamilton Spectator and Globe and Mail, claiming no German threat existed as the RCMP found little or no evidence of Nazi activity ${ }^{23}$ Whitaker and Kealey disagree, using biographies and autobiographies written by security service officials to argue, at the beginning of the war, the RCMP "broke the back of potential Nazi [subversion or sabotage] against the war effort." ${ }^{24}$ Furthermore, Keyserlingk indicates that even if a Nazi threat had existed, they did not have the personnel capacity nor the intelligence capabilities to effectively consider the problem, as illustrated in official memorandums and reports, a history about the RCMP, and an officer's autobiography. ${ }^{25}$ However, Whitaker and Kealey use sources unavailable when “"Agents Within the Gates"” was published, including their own work, RCMP Bulletins, compiling formerly restricted RCMP documents and McBride's Masters thesis about the RCMP to claim they had a network of undercover agents and informants within the

\footnotetext{
${ }^{21}$ Ibid, 211.

${ }^{22}$ See Whitaker and Kealey, 272, 274-275.

${ }^{23}$ Keyserlingk, 237; Whitaker and Kealey, 274.

${ }^{24}$ Whitaker and Kealey, 274.

${ }^{25}$ Keyserlingk, 216-220.
} 
Italian and German communities long before the war and obtained evidence suitable for internment through surveillance and confiscation of property. ${ }^{26}$

Likewise, in "Curious Case of Female Internees," McBride takes advantage of Whitaker and Kealey's RCMP Bulletins and her own Masters thesis, as well as newly released documents in the National Archives of Canada, including records from the RCMP, Norman A. Robertson, an advisor to Prime Minister Mackenzie King, and the Department of the Solicitor General. ${ }^{27}$ Unfortunately, she had to interpret fragments of these redacted documents to obtain any details on female internees, a similar dilemma faced by Sugiman, as Japanese-Canadian correspondence discovered in the National Archives had been "intercepted and censored by government officials during [the Second World War]. ${ }^{28}$ In the same way as Keyserlingk and Whitaker and Kealey, McBride only uses sources to view the circumstances of the arrest and internment of "enemy aliens," relying on communications between the Department of National Defence, RCMP, and prison warden of the Kingston Penitentiary. However, through the IDC personal history files and RCMP reports, she provides interesting personal details about the lives of specific female internees and uncovers their associations with fascist or pro-Nazi organizations. ${ }^{29}$ Nonetheless, statistics from a list of internees on the RCMP Central Registry Classification Sheet illustrate females constituted a very small percentage of interned "enemy aliens," not only making the cases seem exceptional, rather than the norm, but also leading McBride to conclude internment policies set by the IDC were "haphazard" and more women with connections to threatening political organizations

\footnotetext{
${ }^{26}$ McBride, 148; Whitaker and Kealey, 272, 274, 278.

${ }^{27}$ McBride, 148-149.

${ }^{28}$ Sugiman, 253.

${ }^{29}$ McBride, 149-165.
} 
should have been interned. ${ }^{30}$ Although McBride claims her work is an attempt to gender the history of internment, her failure to use any written or oral testimony from female internees weakens this goal. Sugiman, on the other hand, as if answering McBride's call, makes very effective use of letters to and from interned Japanese Canadian women, while also adding oral accounts she herself developed. Thus, Sugiman is the only author to use the perspective of the Japanese internees themselves. Most of the others guide readers to Ken Adachi's The Enemy that Never Was: a History of Japanese Canadians.

The letters and oral testimonies used by Sugiman verify that government policies subjected Japanese Canadians to ethnic discrimination and suggest there was no evidence of any threat that might justify internment. While offering a strong contrast to McBride and Whitaker and Kealey, Sugiman acknowledges the problems with relying on written accounts that were both censored and translated from Japanese. Oral testimony also has limits as memories change over time, sometimes people alter how they recall traumatic events, and sometimes responses are influenced by how the question is asked. ${ }^{31}$ Every historian uses various primary sources, including letters, official documents, newspapers, or oral history, but Sugiman offers a richer account of female "enemy aliens."

In general, each article is strengthened using a range of prime and secondary sources to support their theses, but each author's narrow focus sometimes weakens their arguments. Each of Keyserlingk, McBride, and Whitaker and Kealey rely on one major source and often reject or ignore other findings to the contrary. In its 29 pages, for example, Keyserlingk's "'Agents within the Gates" dedicates two short sentences to the capture of three German spies on Canadian soil, but this evidence is quickly dismissed

\footnotetext{
${ }^{30}$ Ibid, 154-166.

${ }^{31}$ Sugiman, 253-267 and 267.
} 
since they were not from Canada. If he is arguing there were no Nazi collaborators in Canada, then he should have paid more attention to this case. Did they, for example, have connections to people of German descent in Canada? Sugiman, similarly, would benefit from oral testimony from people outside the Japanese-Canadian community, particularly security service officers. Would it not be of interest to know what they thought of the internment and specifically of women's internment? Lastly, McBride and Whitaker and Kealey glaze over the role of the RCMP in the relocation, confiscation of property, and restrictions on the freedom of Japanese Canadians. They emphasize the role of the DOCR arguing that other security agencies were more responsible and that the "actual conduct and conditions of internment were not an RCMP responsibility." ${ }^{32}$ Yet the articles do not contain any primary sources by persons of enemy origin or in unofficial positions as evidence either confirming or denying the RCMP's involvement. How can one really know what the RCMP's involvement was when the evidence base is so narrow? Undoubtedly these authors know the government and the RCMP acted in a discriminatory manner, and no amount of interpretation or evidence can change that fact. While these considerations may have helped form impartial and informed arguments in these articles, the suggestion and questions could also act as a starting point for further historical research on "enemy" internment during the Second World War.

In conclusion, historians differ in their treatment of "enemy alien" internment during the Second World War. All agree that the Canadian government singled out and interned persons of specific ethnic backgrounds, despite no evidence that they posed any legitimate danger to the country. These people offered no real threats to society; they

\footnotetext{
${ }^{32}$ Whitaker and Kealey, 271 and 279.
} 
offered no sense of extreme or subversive ideologies. In all the articles analysed, the personal or academic background, the authors' subjective points-of-view, and their own historical contexts influenced how they interpreted this story. The conclusions of Keyserlingk, McBride, and Whitaker and Kealey demonstrate how historians can analyse and interpret primary sources about one event in several, often opposing, ways.

Ultimately, while Keyserlingk provides adequate evidence of government prejudice towards German Canadians during the Second World War, his assertions of injustice are somewhat exaggerated when compared with the experiences of those of Japanese descent, as Sugiman illustrates. Nevertheless, both authors at least make clear that the Canadian government later attempted to remedy its mistakes, either through admission of wrongdoing, redress settlements, not reinstating the DOCR, and acknowledging its internment was not representative of Canadian laws and ideals. On the other hand, McBride and Whitaker and Kealey seem to misinterpret the situation altogether by suggesting the detainment was duly justified. In a sense, then, these authors were allowing that, in times of war, even in a democracy, the government has the right to strip minorities or nonconformist citizens of their civil liberties. They forget that the reason Canadian soldiers were fighting was to protect those very rights and freedoms. Therefore, it is important for historians to convey how the Canadian government and its security services subjected persons of enemy origins to discriminatory treatment under extreme circumstances of the Second World War. But it is equally important for them to show how Canada differs from its enemies by admitting its faults, making reparations, and ensuring the future protection of the democratic rights and principles of its citizens, regardless of their backgrounds or beliefs. 


\section{Bibliography}

“Greg Kealey.” Department of History, University of New Brunswick. Accessed 23 March 2017.

http://www.unb.ca/fredericton/arts/departments/history/people/gkealey.html

Hillmer, Norman, Bohdan Kordan, and Lubomyr Luciuk, eds. On Guard for Thee: War, Ethnicity, and the Canadian State, 1939-1945. Ottawa, Canadian Committee for the History of the Second World War, 1988.

Keyserlingk, Robert H. "'Agents Within the Gates': the Search for Nazi Subversion in Canada During World War II." Canadian Historical Review 66, no. 2 (June 1985): 211-239.

Keyserlingk, Robert H. Encyclopedia.com. Assessed 23 March 2017. http://www.encyclopedia.com/arts/culture-magazine/keyserlingk -robert-h.html

Martel, Marcel. "Introduction: World War II and the Internment of Enemy Aliens: Circumscribing Personal Freedoms." Visions: The Canadian History Modules Project, Post-Confederation, eds. P.E. Bryden, Colin M. Coates, Maureen Lux, Lynne Marks, Marcel Martel, and Daniel Samson. Toronto, Nelson, 2017. 237238.

McBride, Michelle. "The Curious Case of Female Internees." Enemies Within: Italian and Other Internees in Canada and Abroad, eds. Franca Iacovetta, Roberto Perin, and Angelo Principe. Toronto: University of Toronto Press, 2000. 148-170.

"Pamela Sugiman." Research \& Innovation Spotlight. Ryerson University, Faculty of Arts. Accessed 23 March 2017. http://www.ryerson.ca/arts/researchinnovation/research-and-innovation-spotlight/sugiman-pamela/

Sugiman, Pamela. "Passing Time, Moving Memories: Interpreting Wartime Narratives of Japanese Canadian Women." Visions: The Canadian History Modules Project, Post-Confederation, eds. P.E. Bryden, Colin M. Coates, Maureen Lux, Lynne Marks, Marcel Martel, and Daniel Samson. Toronto, Nelson, 2017. 250-270.

Waiser, Bill. "Wartime Internment: in The Oxford Companion to Canadian History. Oxford University Press, 2004. Accessed 22 March 2017. http://www.oxfordreference.com/view/10.1093/acref/9780195415599.001.0001/a cref-9780195415599-e-1636

Whitaker, Reg and Gregory S. Kealey. "A War on Ethnicity? The RCMP and Internment." Visions: The Canadian History Modules Project, PostConfederation, eds. P.E. Bryden, Colin M. Coates, Maureen Lux, Lynne Marks, Marcel Martel, and Daniel Samson. Toronto, Nelson, 2017. 237-238. 